\title{
TATA KELOLA AIR TERJUN MATA BUNTU DI KECAMATAN WASUPONDA KABUPATEN LUWU TIMUR
}

\section{Management of Mata Buntu Waterfall in Wasuponda District, East Luwu Regency}

\author{
Jusmiati \\ Politeknik Pariwisata Makassar \\ Jl. Gunung Rinjani, Kota Mandiri Tanjung Bunga, Makassar \\ Email: jusmiatiw2@gmail.com \\ Muh. Arfin M. Salim \\ Politeknik Pariwisata Makassar \\ Jl. Gunung Rinjani, Kota Mandiri Tanjung Bunga, Makassar \\ Email: arfin70@yahoo.com
}

\begin{abstract}
This study aims to determine the management of Mata Buntu Waterfall in Wasuponda East Luwu regency and create the concept for the governance of Mata Buntu Waterfall for more directed management. This research uses descriptive qualitative analysis method. Technique of collecting data is done by interview, observation and documentation. The results showed that the management of Mata Buntu Waterfall was done by the local people independently. The concept of governance that can be applied in tourist attraction Mata Buntu Waterfall is by using management functions and stakeholder involvement.
\end{abstract}

Keywords: Governance, Mata Buntu Waterfall, management function, stakeholder 


\section{PENDAHULUAN}

Kabupaten Luwu Timur merupakan salah satu kabupaten yang memiliki potensi wisata yang dapat dikunjungi oleh wisatawan. Potensi wisata yang dimiliki diantaranya Pantai Lemo, Air Terjun Salu Anuang, Sungai Malili, Air Terjun Mata Buntu, Air Terjun Atue, Danau Matano, Danau Towuti, Pesona Bawah Laut Bulu' PoloE, dan Pantai Batu Menggoro (www.luwutimurkab.go.id). Dari sekian banyak potensi wisata yang dimiliki oleh Kabupaten Luwu Timur, Air Terjun Mata Buntu merupakan salah satu dari empat tempat wisata yang paling banyak dikunjungi oleh wisatawan. Hal ini sesuai dengan penyataan dikemukakan oleh Kepala Dinas Pariwisata, Kebudayaan, Kepemudaan dan Olahraga Kabupaten Luwu Timur (www.palopopost.fajar.co.id).

Adapun data kunjungan wisatawan di Kabupaten Luwu Timur tercatat jumlah kunjungan wisatawan di Kabupaten Luwu Timur pada tahun ke tahun terus meningkat yaitu pada tahun 2011 berjumlah 1.945 kunjungan wisatawan, 2012 berjumlah 2.042 jiwa, 2013 berjumlah 2.144 jiwa, 2014 berjumlah 2.251 jiwa, 2015 berjumlah 2.363 jiwa dan pada tahun 2016 wisatawan yang berkunjung berjumlah 2.410 jiwa (Dinas Pariwisata, Kebudayaan, Kepemudaan dan Olahraga Kabupaten Luwu Timur, 2017).

Kepala Dinas Pariwisata, Kebudayaan, Kepemudaan dan Olahraga Kabupaten Luwu Timur mengatakan pada tahun ini akan fokus membenahi empat potensi wisata unggulan yang ada di Kabupaten Luwu Timur yaitu Danau Matano, Sungai Malili hingga wisata Laut Bulu’ PoloE, Pantai Lemo, dan Air Terjun Mata Buntu. Hal ini dilakukan karena sesuai hasil evaluasi di tahun 2016, keempat potensi wisata tersebut yang paling ramai dikunjungi oleh wisatawan (palopopos, Kamis 12 Januari 2017).

Melalui pertimbangan untuk meminimalkan atau bahkan menghapus kesenjangan antara keuntungan dan kerugian terhadap pengembangan sektor pariwisata, dibutuhkan sebuah pengelolaan (manajemen) yang baik layaknya tata kelola terhadap berbagai bentuk pengembangan lainnya. Hal ini berlaku pula terhadap pengelolaan di Air Terjun Mata Buntu Kabupaten Luwu Timur.

Dari hasil observasi pertama dan wawancara yang telah dilakukan dengan kepala seksi promosi, objek dan daya tarik wisata mengatakan "pengembangan Air Terjun Mata Buntu memang masih kurang, hal tersebut disebabkan oleh beberapa faktor. Diantaranya, kurangnya SDM dan anggaran untuk mengelola Air Terjun Mata Buntu dan sebagian lahan di sekitar tempat wisata merupakan milik masyarakat" (10 Mei 2017). Penulis juga menemukan kekurangan di daya tarik wisata Air Terjun Mata Buntu setelah melakukan observasi pertama. Diantaranya, sempitnya jalan untuk menuju ke tempat wisata, rusaknya sebagian jalan, kurangnya papan petunjuk arah, tidak adanya tempat sampah, pegangan tangga yang rusak, serta tidak adanya papan informasi atau zona regulasi. Selain itu, di daerah sekitar puncak air 
terjun merupakan lahan perkebunan milik masyarakat yang suatu saat akan merusak air terjun mata buntu.

Untuk menjadikan Air Terjun Mata Buntu sebagai tempat wisata unggulan di Kabupaten Luwu Timur, dibutuhkan pengelolaan yang optimal baik partispasi masyarakat ataupun peran pemerintah. Sampai saat ini, pengelolaan di Air Terjun Mata Buntu dilakukan secara lokal yaitu masyarakat setempatdengan arahan Kepala Desa Ledu-Ledu. Beberapa kegiatan yang teah dilakukan oleh masyarakat dalam pengelolaan Air Terjun Mata Buntu diantaranya yaitu bergotong royong dalam memperbaiki jalan yang rusak menuju ke tempat wisata, membuka kios-kios, dan membuka lahan pakir.

Dari hasil wawancara yang telah dilakukan penulis dengan Kepala Desa Ledu-ledu, beliau mengatakan "pengelolaan yang dilakukan oleh masyarakat terhadap Air Terjun Mata Buntu masih kurang, hal ini dikarenakan belum adanya komitmen pemerintah dalam pengelolaan pariwsata dan itu dapat dilihat dari belum adanya PERDA yang dikeluarkan oleh pemerintah tentang pariwisata di Kabupaten Luwu Timur". Berkaitan dengan pernyataan Kepala Desa di atas, penulis melanjutkan wawancara dengan salah satu masyarakat dan beliau mengatakan "pengelolaan yang telah kami lakukan hanya sebatas kemampuan kami saja".

Pengelolaan Air Terjun Mata Buntu dilakukan sebatas kemampuan dari pihak pengelola. Masyarakat setempat hanya melakukan pengelolaan secara mandiri, dan masyarakat melakukan pengelolaan hanya pada hal yang menguntungkan masyarakat contohnya penyediaan lahan parkir yang disediakan oleh pemilik lahan dan penyediaan kios, sehingga masyarakat tidak memperhatikan kondisi lingkungan pada tempat wisata contohnya banyaknya sampah dan kurangnya perawatan terhada fasilitas di Air Terjun Mata Buntu. Hai ini disebabkan karena kurangnya keterlibatan pemerintah daerah untuk pengembangan Air Terjun Mata Buntu, kurangnya SDM yang berpengalaman mengenai pariwisata, kurangnya dana serta kurangnya pemahaman masyarakat setempat mengenai pariwisata, utamanya dalam pengelolaan dan pengembangan pariwisata. Maka dalam konteks ini dibutuhkan pengelolaan berupa tata kelola yang baik agar pengelolaan Air Terjun Mata Buntu dapat terarah.

Tata kelola yang dimaksud dalam hal ini adalah kerjasama yang baik antara pemerintah dan masyarakat, baik dalam hal kejelasan pengelolaan maupun pengelolaan secara internal. Sehubungan dengan tata kelola yang dimaksud, maka dibutuhkan pendekatan dan dibutuhkan suatu model agar tata kelola yang diinginkan mampu tercipta atau mampu direalisasikan untuk mengoptimalkan potensi yang dimiliki oleh Air Terjun Mata Buntu, karena dengan tata kelola yang baik atau model pendekatan yang bisa digunakan, baik pendekatan yang menyentuh kepada masyarakat dan melibatkan 
pemerintah itu sangat dibutuhkan. Maka dari uraian di atas penulis mengangkat penelitian dengan judul "Tata Kelola Air Terjun Mata Buntu di Wasuponda Kabupaten Luwu Timur". Rumusan masalah dalam penelitian ini yaitu: Bagaimana konsep tata kelola Air Terjun Mata Buntu di Wasuponda Kabupaten Luwu Timur?

\section{TINJAUAN PUSTAKA}

\section{Konsep Tata Kelola Pariwisata}

Soedjadi (2000) mengemukakan bahwa, konsep adalah ide abstrak yang dapat digunakan untuk menyimpan klasifikasi atau kategorisasi umumnya dinyatakan dengan istilah atau serangkaian kata. Umar (2004) konsep adalah sejumlah teori yang berkaitan dengan suatu objek. Konsep diciptakan dengan menggolongkan dan mengelompokkan objek-objek tertentu yang mempunyai ciri-ciri yang sama.

Djamarah (2008) pengertian konsep adalah unit yang mewakili sejumlah objek yang memiliki karakteristik yang sama. Orang-orang yang memiliki konsep mampu membuat abstraksi dari obyek yang dihadapi, sehingga objek ditempatkan dalam kelompok-kelompok tertentu. Singarimbun dan Effendi (2009), konsep adalah generalisasi dari kelompok tertentu dari fenomena, sehingga dapat digunakan untuk menggambarkan fenomena barbagai yang sama.

Kamus Besar Bahasa Indonesia mengemukakan pengertian tata kelola adalah (1) tata merupakan cara dan (2) kelola merupakan mengelolah, jadi secara garis besar tata kelola dapat di artikan "cara pengelolaan".

Tata kelola destinasi pariwisata adalah sebuah system yang mengfasilitasi organisasi pariwisata dengan berbagai alat yang menciptakan destinasi pariwisata yang berkelanjutan dan berdaya saing. Tata kelola destinasi pariwisata dihasilkan melalui sebuah proses yang melibatkan kolaborasi, kerja sama dan kepemimpinan dalam mencari pemahaman yang sama. Proses tata kelola kerap membutuhkan negosiasi poitik terus-menerus, pembelajaran yang berkesinambungan dan sebuah model bisnis dengan toleransi error yang tinggi. Target yang ingin dicapai harus merupakan integrasi berbagai kepemimpnan dan keselarasan tujuan. Ada banyak cara kerjasama yang memungkinkan yang bisa diperkenalkan untuk meingkatkan daya saing dan inovasi pada sebuah destinasi pariwisata. Sebuah upaya awal dalam memberikan model organisasi teoritis untuk destinasi yang sudah terkelola baik skala kecil maupun menengah yang sedang berada pada tahap stegnan. (Ghirelli, 2013 dalam Teguh, 2015).

Menurut Pitana dan Diarta (2009), pengelolaan pariwisata harus memperhatikan prinsip-prinsip sebagai berikut: 
1. Pembangunan dan pengembangan pariwisata haruslah didasarkan pada kearifan lokal dan special local sense yang merefleksikan keunikan peninggalan budaya dan keunikan lingkungan.

2. Preservasi, proteksi, dan peningkatan kualitas sumber daya yang menjadi basis pengembangan kawasan pariwisata.

3. Pengembangan atraksi wisata tambahan yang mengakar pada khasanah budaya dan lingkungan lokal.

4. Pelayanan kepada wisatawan yang berbasis keunikan budaya dan lingkungan social.

5. Memberikan dukungan dan legitimasi pada pembangunan dan pengembangan pariwisata jika terbukti memberikan manfaat positif, tetapi sebaliknya mengendalikan dan atau menghentikan aktivitas pariwisata tersebut jika melampaui ambang batas lingkungan alam atau akseptabilitas sosial walaupun disisi lain mampu meningkatkan pendapatan masyarakat.

Terry (2000) mengemukakan fungsi manajemen:

1. Perencanaan (planning) yaitu sebagai dasar pemikiran dari tujuan dan penyusunan langkah-langkah yang akan dipakai untuk mencapai tujuan. Merencanakan berarti mempersiapkan segala kebutuhan, memperhitungkan matang-matang apa saja yang menjadi kendala, dan merumuskan bentuk pelaksanaan kegiatan yang bermaksud untuk mencapai tujuan.

2. Pengorganisasian (organizing) yaitu sebagai cara untuk mengumpulkan orang-orang dan menempatkan mereka menurut kemampuan dan keahliannya dalam pekerjaan yang sudah direncanakan.

3. Penggerakan (actuating) yaitu untuk menggerakan organisasi agar berjalan sesuai dengan pembagian kerja masing-masing serta menggerakan seluruh sumber daya yang ada dalam organisasi agar pekerjaan atau kegiatan yang dilakukan bisa berjalan sesuai rencana dan bisa mencapai tujuan.

4. Pengawasan (controlling) yaitu untuk mengawasi apakah gerakan dari organisasi ini sudah sesuai dengan rencana atau belum. Serta mengawasi penggunaan sumber daya dalam organisasi agar bisa terpakai secara efektif dan efisien tanpa ada yang melenceng dari rencana.

\section{Partisipasi Masyarakat}

Partisipasi berasal dari bahasa Inggris yaitu "participation". Menurut Davis (2000), partisipasi adalah keterlibatan mental dan emosional seseorang/individu dalam situasi kelompok yang mendorong dia untuk berkontribusi terhadap tujuan kelompok dan mempertanggung jawabkan 
keterlibatannya. Hal ini berarti partisipasi adalah suatu kegiatan dimana orang diikutsertakan dalam perencanaan serta dalam pelaksanaan dan ikut memikul tanggungjawab sesuai dengan tingkat kematangan dan tingkat kewajibannya.

Munas (2011) mengemukakan bahwa partisipasi masyarakat merupakan tindakan masyarakat yang ikut serta dalam kegiatan mulai dari tahap persiapan, perencanaan, design, pelaksanaan maupun monitoring dan evaluasi. Huraerah (2008) mengemukakan bahwa pada dasarnya ada beberapa bentuk partisipasi yang dapat diberikan masyarakat dalam mendukung sebuah program pembangunan yang dikelompokkan ke dalam 2 jenis, yaitu partisipasi yang nyata (memiliki wujud) misalnya uang, harta benda, tenaga, serta partisipasi yang tidak nyata (abstrak) seperti buah pikiran, pengambilan keputusan dan partisipasi representatif.

Huraerah (2008) membahas mengenai bentuk-bentuk partisipasi masyarakat, yaitu:

1. Partisipasi berupa ide atau buah pikiran dalam sebuah rapat, pertemuan maupun musyawarah.

2. Partisipasi berupa tenaga yang diberikan dalam membantu kegiatan seperti perbaikan dan pembangunan desa, pertolongan bagi orang lain dan sebagainya.

3. Partisipasi berupa harta benda baik dalam bentuk uang, makanan dan sebagainya yang dapat diberikan kepada pihak yang melakukan perbaikan dan pembangun desa, pertolongan bagi orang lain dan sebagainya.

4. Partisipasi berupa keterampilan dan kemarihan yang diberikan dan berguna bagi orang dalam mendorong munculnya berbagai bentuk usaha dan industry.

5. Partisipasi sosial yang diberikan kepada orang lain sebagai simbol dari hubungan sosial yang baik.

\section{METODOLOGI PENELITIAN Objek dan Lokasi Penelitian}

Penelitian menggunakan pendekatan qualitatif, sehingga data yang digunakan adalah data kualitatif. Data Kualitatif adalah tangkapan atas perkataan subjek penelitian dalam bahasanya sendiri. Pengalaman orang diterangkan secara mendalam, menurut makna kehidupan, pengalaman dan interaksi sosial dari subjek penelitian sendiri. Dengan demikian, penelitianmendalami kondisi masyarakat menurut pengertian mereka sendiri.

Untuk sumber data terdiri atas dua sumber yaitu data primer yang diperoleh dengan melakukan wawancara secara langsung kepada pihak-pihak yang terkait da data sekunder yang diperoleh melalui data yang dikumpulkan, 
referensi yang berasal dari buku-buku serta contoh penulisan ilmiah lainnya yang berkaitan dengan masalah penelitian.

Teknik analisis data yang digunakan dalam penelitian ini adalah menggunakan metode deskriptif kualitatif yaitu prosedur yang dilakukan dengan menggunakan sumber-sumber secara tertulis yang diperoleh dari hasil observasi dan secara lisan yang diperoleh dari hasil wawancara. Supaya data yang diperoleh dilapangan bermakna, maka analisisnya dibantu dengan checklist dan panduan wawancara yang diutarakan dengan ekstrak. Teori yang digukan untuk menjawab pokok masalah yaitu teori dari Terry (2000) mengenai fungsi manajemen (POAC), Pitana dan Diarta (2009) mengenai prinsip-prinsip yang harus diperhatikan dalam pengelolaan pariwisata dan Huraera (2008) mengenai bentuk-bentuk partisipasi masyarakat.

\section{HASIL PENELITIAN DAN PEMBAHASAN Gambaran Umum Objek Penelitian}

Air Terjun Mata Buntu terletak di Desa Ledu-ledu, Kecamatan Wasuponda, Kabupaten Luwu Timur, Provinsi Sulawesi Selatan. Air Terjun Mata Buntu merupakan salah satu tempat wisata unggulan yang terdapat di Kabupaten Luwu Timur. Air Terjun Mata Buntu dikenal dengan keunikan memiliki bebatuan atau tebing yang dilalui aliran air yang berbentuk mangkuk dengan 33 tingkatan tebing. Dari 33 tingkatan tebing tersebut ada 6 tebing yang paling tinggi. Selain itu keunikan lainnya yaitu bebatuan pada Air Terjun Mata Buntu tersebut tidak licin walaupun telah berlumut. Air terjun ini dikelilingi dengan pepohonan yang lebat karena Air Terjun Mata Buntu berada pada Kawasan Hutan Lindung.

Wisatawan yang berkunjung ke Air Terjun Mata Buntu dapat menikmati keindahan puluhan susunan tebing ait terjun yang berbentuk secara alami. Karena susunan tersebut ada 33 tingkatan, maka untuk menuju ke tingkatan paling atas wisatawan dapat menaiki ratusan anak tangga yang berada tepat di samping air terjun.

\section{Kondisi Faktual Air Terjun Mata Buntu}

Atraksi wisata yang dimiliki oleh Air Terjun Mata Buntu yaitu susunan tingkatan tebing yang dialiri air. Aktivitas yang dapat dilakukan wisatawan jika berkunjung ke Air Terjun Mata Buntu yaitu menikmati keindahan alam, merasakan segarnya air di tempat tersebut dengan suara gemuruh dari Air Terjun.

Tempat wisata ini berjarak $3 \mathrm{Km}$ dari pusat kota Wasuponda atau sekitar 30 menit sedangkan waktu tempuh menuju ke Air Terjun Mata Buntu dari Ibukota Kabupaten yaitu Kota Malili sekitar sekitar 90 menit. Dapat di jangkau dengan menggunakan kendaraan roda dua dan roda empat. Di sepanjang jalan menuju ke Air Terjun Mata Buntu dari Desa Ledu-ledu, 
wisatawan akan dimanjakan dengan pemandangan alam yang indah. Akses yang ditempuh menuju ke Air Terjun Mata Buntu cukup sulit, karena keadaan jalan yang kurang baik. Dalam hal ini sebagian jalannya rusak serta jalan akses menuju ke tempat wisata masih sempit.

Sebagai daerah tujuan wisata yang ramai dikunjungi oleh wisatawan maka pihak pengelola baik itu pemerintah daerah, masyarakat ataupu stakeholder lainnya, sebaiknya menyediakan fasilitas-fasilitas untuk memudahkan setiap aktivitas wisatawan mulai dari fasilitas pendukung hingga fasilitas penunjang. Fasilitas pendukung yang tersedia di Air Terjun Mata Buntu yaitu terdapat kios atau warung yang melayani wisatawan untuk berbelanja cemilan ataupun makanan dan minuman; tempat penyewaan alat piknik seperti alat pembakaran ikan/jagung, piring dan sendok dengan harga Rp30.000; Kurangnya papan petunjuk arah, hanya ada satu petunjuk arah menuju ke tempat wisata yaitu hanya di jalan poros/utama....; Gerbang; Terpat parkir; pos penjagaan; MCK/ruang ganti; Tangga; Tempat duduk/Gazebo. Berikut gambar-gambar untuk amenitas yang ada di Air Terjun Mata Buntu.

Walaupun Air Terjun Mata Buntu masuk dalam kawasan hutan lindung namun pengelolaannya dilakukan oleh masyarakat lokal dengan arahan dari kepala desa setempat. Masyarakat setempat sebagai pihak pengelola telah bekerjasama dengan Dinas Kehutanan (KPHL) Kabuapaten Luwu Timur dan Pemerintah Daerah (Dinas Pariwisata Kabupaten Luwu Timur).

Salah satu bentuk kerjasamanya yaitu pembangunan tangga di dalam kawasan hutan lindung, hal ini sesuai dengan hasil wawancara dengan kepala desa yang menyatakan bahwa pembangunan anak tangga dilakukan bersamaan dengan pembangunan jalan beraspal menggunakan dana APBD melalui Dinas Pariwisata Luwu Timur. Hal ini dilakukan karena pemerintah daerah telah menyadari potensi yang dimiliki oleh Air Terjun Mata Buntu. Pembangunan tangga di dalam kawasan hutan lindung yang berada tepat di samping kiri air terjun merupakan bukti kerjasama antar instansi dalam pengelolaan Air Terjun Mata Buntu.Tujuan dari pembuatan tangga yaitu agar memudahkan wisatawan menuju ke puncak tebing air terjun. Tentu saja hal ini disesuaikan dengan syarat pembangunan yang tidak merusak alam atau pembangunan hanya sekedar tangga sehingga alam masih tetap terjaga.

Dalam pembuatan fasilitas tangga yang telah dilakukan oleh pihak Dinas Pariwisata Kabupaten Luwu Timur, Dinas Kehutanan melalui KPHL Kabupaten Luwu Timur hanya berpesan agar tetap menjaga kealamiahan dari hutan tersebut dan apabila ingin melakukan pembangunan fasilitas lainnya di kawasan hutan lindung harus tetap melapor dan meminta izin. Hal ini sesuai dengan penyataan ketua KPHL (Kesatuan Pengelolaan Hutan Lindung) Luwu Timur. 


\section{Ekstrak1}

“... Dinas Kehutanan telah memberika izin kepada Dinas Pariwisata untuk membangun tangga namun tetap dengan syarat, pembangunan hanya sekedar tangga supaya alam hutan tetap terjaga..."(Agg, 03 Juli 2017)

Ekstrak 1 menjelaskan bahwa izin yang telah diberikan oleh Dinas Kehutanan untuk pembuatan ratusan anak tangga harus tetap memperhatikan peraturan dan syarat yang telah disepakati, yaitu dalam pembangunan ratusan anak tangga tidak boleh merusak hutan lain diluar dari pembangunan tangga termasuk pembangunan gazebo/tempat istirahat, Dinas Pariwisata harus tetap memperhatikan kelestarian alam. Mengenai pengelolaan di Air Terjun Mata Buntu, Dinas Pariwisata hanya menyediakan fasilitas yang dibutuhkan oleh wisatawan di tempat tersebut. Selanjutnya dari pihak pengelola yaitu masyarakat bertanggung jawab untuk menjaga fasilitas yang telah disediakan. Hal ini diperkuat dengan pernyataan staf Dinas Pariwisata.

\section{Ekstrak 2}

“...pengelolaanya itu dilakukan oleh lokal (masyarakat setempat), kami disini hanya membantu mengfasilitasi yang dibutuhkan oleh wisatawan. Jadi masyarakat disana yang merawat dari setiap fasilitas yang sudah kami sediakan..."(Hsr, 09 Juni 2017). Ekstrak 2 menjelaskan bahwa Dinas Pariwisata bukan sebagai pengelola walaupun mereka telah menyediakan fasilitas yang dibutuhkan di tempat wisata tersebut. Pengelolaan Air Terjun Mata Buntu dilakukan oleh masyarakat setempat, masyarakat setempat yang melakukan perlindungan, perawatan dan penjagaan dari setiap fasilitas yang telah tersedia dan bersama-sama tetap merawat dan melindungi hutan lindung utamanya Air Terjun Mata buntu serta menata dan membangun, memperindah.

\section{Ekstrak 3}

dapat resmi dilakukan oleh desa, karena kalau sudah ada peraturan maka otomatis dana pengelolaan juga bakalan ada dan itu sangat membantu dalam pengembangan potensi wisata Air Terjun Mata Buntu..." (Ahm, 04 Juli 2017). Pernyataan dalam ekstrak 3 tersebut dilanjutkan dengan "jika PERDES dan BUMDES telah diresmikan, maka pembangunan anak tangga di samping sebelah kanan air terjun akan dilanjutkan. Pemanfaatan tanaman liar yang terdapat di kawasan hutan lindung seperti bunga anggrek dengan menempelkan setiap bunga tersebut di batu/pohon di samping tangga menjadi prioritas. Hal ini bertujuan untuk lebih memperindah kawasan tersebut. Hasil wawncara dalam extrak 1 menunjulkan mengfasilitasi daerah di sekitar Air Terjun Mata Buntu yang tentunya diluar dari kawasan hutan lindung agar wisatawan dapat senang berkunjung ke tempat tersebut.

Di dalam hasil wawancara yang telah dilakukan oleh peneliti dengan Kepala Desa Ledu-ledu yang memberikan arahan kepada masyarakat setempat dalam pengelolaan, penulis memberikan pertanyaan "apakah ada 
konsep yang bapak sudah fikirkan, yang akan diterapkan di Air Terjun Mata Buntu untuk pengelolaan selanjutnya?". Kepala Desa mengutarakan pendapatnya mengenai tata kelola yang akan dilaksanakan selanjutnya.

\section{Ekstrak4}

“...Desa berencana membuat PERDES (Peraturan Desa) untuk pelaksanaan BUMDES (Badan Usaha Miik Desa) agar supaya pengelolaan Air Terjun Mata Buntu. Pernyataan dalam ekstrak 4 menjelaskan bahwa pemanfaatan dana pengelolaan dengan jasa keamanan, kebersihan dan maintenance di tempat wisata Air Terjun Mata Buntu akan diatur dalam suatu peraturan desa dan pengelolaannya akan diserhakan kepada lembaga resmi seperti BUMDES.

\section{Tata Kelola dengan Menggunakan Fungsi Manajemen}

Dalam pembuatan komsep tata kelola maka diperlukan landasan teori yang berhubungan dengan pengelolaan sehingga konsep pengelolaan dapat terarah. Berikut konsep pengelolaan yang dapat diterapkan di Air Terjun Mata Buntu dengan menggunakan teori dari Terry (2000) mengenai fungsi manajemen yaitu POAC (Planning, Organizing, Actuating dan Controlling).

1. Planning (Perencanaan)

Pengelolaan di Air Terjun Mata Buntu dilakukan oleh masyarakat setempat dengan arahan dari kepala desa setempat. Saat ini, kepala desa telah membuat perencanaan pengelolaan Air Terjun Mata Buntu untuk selanjutnya, sesuai dengan hasil wawancara yang telah dilakukan "Desa berencana membuat PERDES (Peraturan Desa) untuk pelaksanaan BUMDES (Badan Usaha Miik Desa) agar supaya pengelolaan Air Terjun Mata Buntu dapat resmi dilakukan oleh desa, karena kalau sudah ada peraturan maka otomatis dana pengelolaan juga bakalan ada dan itu sangat membantu dalam pengembangan potensi wisata Air Terjun Mata Buntu", "jika PERDES dan BUMDES telah diresmikan, maka kami akan mengajukan untuk pembangunan anak tangga di samping sebelah kanan air terjun. Kami juga akan memanfaatkan tanaman liar yang terdapat di kawasan hutan lindung seperti bunga anggrek dengan menempelkan setiap bunga tersebut di batu/pohon di samping tangga, hal ini bertujuan untuk lebih memperindah kawasan tersebut. Selain itu, kami akan memanfaatkan dana pengelolaan dengan jasa keamanan, kebersihan dan maintenance di tempat wisata Air Terjun Mata Buntu" (Ahm, 2017).

Sesuai dengan penyataan di atas, kepala desa berharap agar peratutan desa yang telah mereka buat dapat disetujui agar semua perencanaan dalam pengelolaan dan pengembangan terhadap Air Terjun Mata Buntu dapat terlaksana. 
Saat ini fasilitas anak tangga yang terdapat di Air Terjun Mata Buntu hanya ada satu yaitu berada di samping kiri air terjun. Jika rencana yang telah dibuat dengan membangun satu tangga lagi disebelah kanan air terjun dapat diizinkan, maka aturan dalam pemanfaatan tangga tersebut akan dilakukan yaitu sebelah kiri merupakan tengga yang dilalui oleh wisatawan untuk naik ke puncak tebing air terjun dan tangga sebelah kanan akan difungsikan sebagai tangga yang dilalui oleh wisatawan untuk turun dari puncak air terjun.

Konsep Tata Kelola Dengan Menggunakan Fungsi Manajemen (POAC)

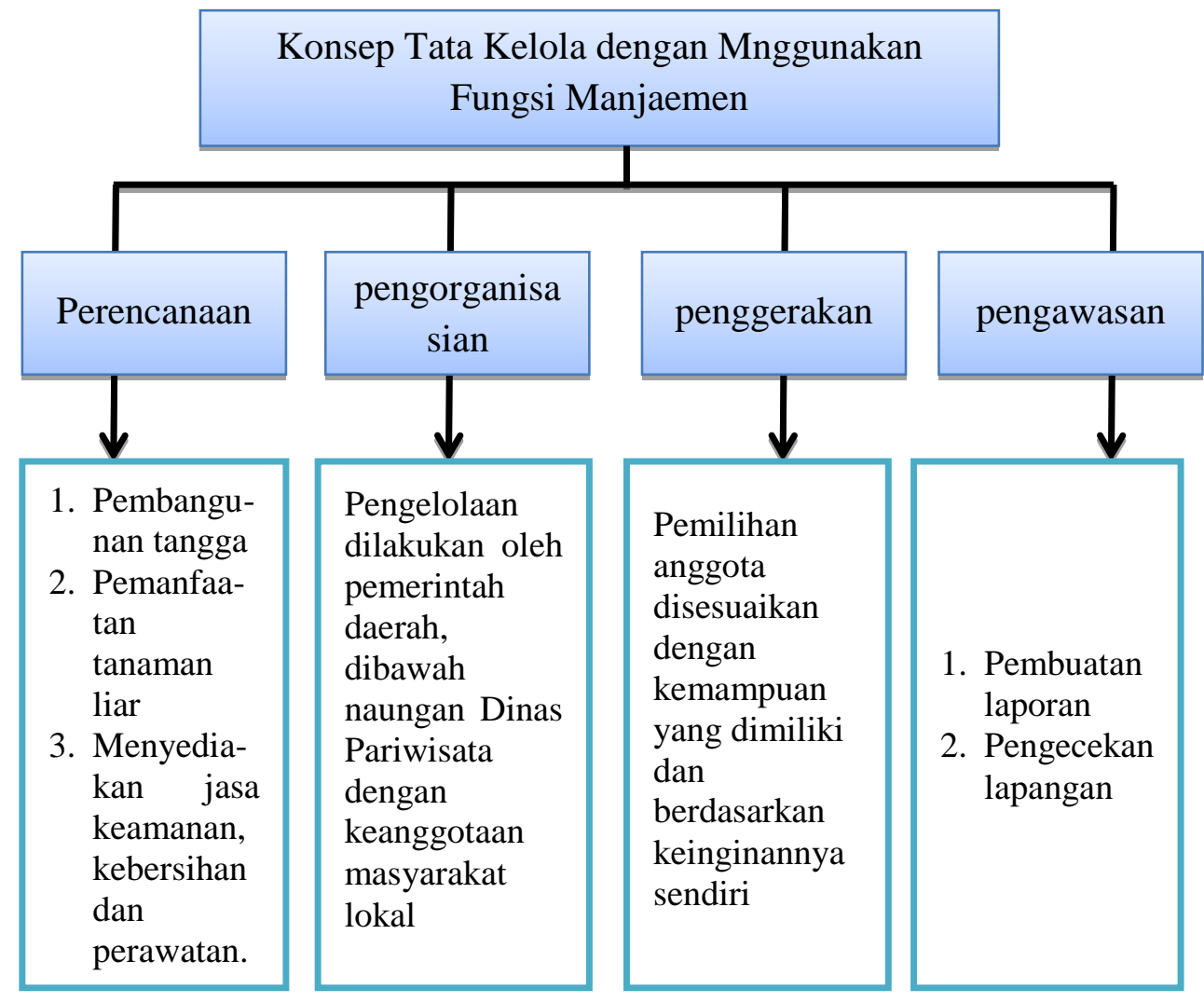

Selanjutnya, mengenai pemanfaatan tanaman liar yang tersembunyi di dalam hutan lindung seperti bunga anggrek dapat dimanfaatkan dengan menempelkan bunga tersebut pada pohon atau batu yang terletak di samping tangga atau di daerah yang dapat dijangkau oleh mata wisatawan. Pemanfaatan bunga anggrek bertujuan untuk memperindah kawasan wisata 
dan memberikan dampak positif mengenai edukasi dalam mengenal tumbuhan langka khas daerah Kecamatan Wasuponda.

Jasa keamanan yang terdapat di tempat wisata Air Terjun Mata Buntu hanya dapat dilaksanakan pada waktu-waktu tertentu yaitu hanya pada hari raya (lebaran Idul Fitri dan Idul Adha) dan tahun baru (masehi). Jasa keamanan seharusnya dapat dilakuakn setiap saat bukan hanya pada waktuwaktu tertentu. Dalam hal ini, jasa keamana dapat dilakukan oleh masyarakat setempat selaku pengelola, masyarakat yang rumahnya berada tidak jauh dari tempat wisata atau mungkin masyarakat yang dibentuk khusus untuk jasa keamanan misalnya komunitas pecinta alam di Kecamatan Wasuponda ataupun di Desa Ledu-ledu.

Karena kondisi Air Terjun Mata Buntu yang kotor, seharusnya disediakan tempat sampahyang diletakkan disetiap titik-titik tertentu, semakin banyak tempat sampah yang disediakan akan lebih baik agar wisatawan sadar akan pentingnya menjaga kebersihan lingkungan.

Perawatan atau maintenance juga sangat dibutuhkan di Air Terjun Mata Buntu. Merawat lingkungan agar tetap indah merupakan hal yang penting pada suatu daya tarik wisata, agar wisatawan senang dan berkeinginan untuk berkunjung kembali. Pihak yang bertugas untuk merawat tempat wisata harus selalu memperhatikan setiap kondisi dari fasilitas yang terdapat di tempat wisata, jika pada saat itu terdapat kerusakan fasilitas, maka harus segera melaoporkan hal tersebut kepada ketua pengelola, agar fasilitas tersebut dapat diperbaiki atau di ganti dengan yang baru. Hal ini tentu bertujuan untuk menjaga fasilitas pendukung agar tetap.

\section{Organizing (Pengorganisasian)}

Pembuatan struktur organisasi sangat dibutuhkan dalam pengelolaan atau manajemen, agar setiap ketua bagian atau ketua penanggung jawab dapat melakukan tugasnya sesuai dengan yang telah disepakati bersama. Masyarakat setempat dibagi dan dibentuk dalam setiap tim sesuai dengan kemampuan masing-masing agar pengembangan Air Terjun Mata Buntu dapat dilakukan sesuai dengan yang diinginkan.

Dalam hal ini kerjasama dengan Dinas Pariwisata Kabupaten Luwu Timur sangat dibutuhkan. Masyarakat yang tidak begitu mengerti mengenai pengelolaan pariwisata sangat membutuhkan acuan dari Dinas Pariwisata.Acuan dari Dinas Pariwisata dapat berupa pengetahuan dan bimbingan tentang bagaimana cara melakukan pengelolaan.

Selain sebagai pengarah dalam pengelolaan Air Terjun Mata Buntu, Dinas Pariwisata juga dapat menjadi bagian dari struktur organisasi dan pelaksana dalam pengelolaan. Dalam hal ini, SDM dari Dinas Pariwisata dapat ikut andil dalam pengelolaan dengan menjadi ketua pelaksana atau ketua bidang dan masyarakat sebagai anggota pelaksana. 


\section{Actuating (penggerakan)}

Untuk membuat semua sumber daya dalam organisasi melakukan tugasnya masing-masing, maka hal pertama yang harus dilakukan oleh ketua pengelola yaitu sebelum membuat struktur organisasi pengelolaan, SDM yang akan ditempatkan pada setiap bagian dalam struktur organisasi harus yang benar-benar berkeinginan ikut serta dalam melakukan pengelola Air Terjun Mata Buntu dan bukan karena unsur paksaan.

Untuk membuat setiap anggota organisasi melaksanakan tugasnya maka dibutuhkan peraturan-peraturan tertentu yang dapat mendorong setiap anggota melaksanakan tugas dan fungsinya masing-masing sesuai dengan kesepakatan yang telah dilakukan. Apabila setiap anggota tidak melakukan tugasnya maka akan diberikan sanksi ringan (surat peringatan tertulis hingga pemotongan gaji) hingga sanksi berat (pemecatan).

4. Controlling (Pengawasan)

Kegiatan pengawasan dalam hal ini yaitu setiap kepala bidang harus membuat laporan pelaksanaan kegiatan setiap sebulan sekali dan diberikan kepada ketua pengelolaan Air Terjun Mata Buntu. Selanjutnya ketua pengelolaan Air Terjun Mata Buntu memberikan laporan kepada Dinas Pariwisata tentang pengelolaan dan pengembangan di Air Terjun Mata Buntu. Selain itu, ketua pengelolaan berkunjung ke Air Terjun Mata Buntu untuk melakukan pengecekan apakah laporan yang dibuat sesuai dengan data yang ada di lapangan.

\section{Keterlibatan Stakeholder dalam Tata Kelola}

Dalam pengelolaan daya tarik wisata maupun destinasi wisata, peran setiap stakeholder sangat penting baik itu pemerintah daerah, masyarakat setempat atapun pihak swasta. Dalam mengelola sebuah daya tarik wisata maupun destinasi wisata, pihak pengelola ataupun stakeholder lainnya harus memiliki sebuah kerangka kerja agar kedepannya tercipta sebuah pengelolaan dan pengembangan pariwisata yang terencana. Hal ini bertujuan untuk memperoleh manfaat secara menyeluruh, baik dari segi perekonomian, sosial masyarakat maupun kebudayaan local.

Dalam konsep pengelolaan di Air Terjun Mata Buntu, peran stakeholder yang dimaksud dalam hal ini yaitu Masyarakat setempat (pengelola Air Terjun Mata Buntu), Dinas Pariwisata, Kebudayaan, Kepemudaan dan Olahraga Kabupaten Luwu Timur dan KPHL (Kesatuan Pengelolaan Hutan Lindung) Kabupaten Luwu Timur.

Dalam konsep tata kelola Air Terjun Mata Buntu, Dinas Pariwisata, Kebudayaan, Kepemudaan dan Olahraga Kabupaten Luwu Timur akan mengambil alih pengelolaan Air Terjun Mata Buntu. Pengelolaan yang dilakukan oleh Dinas Pariwisata yaitu mendapatkan izin dari Dinas 
Kehutanan melalui KPHL Kabupaten Luwu Timur, karena Air Terjun Mata Buntu masuk dalam kawasan hutang lindung.

Konsep Tata Kelola oleh Dinas Pariwisata, Kebudayaan, Kepemudaan dan Olahraga Kabupaten Luwu Timur

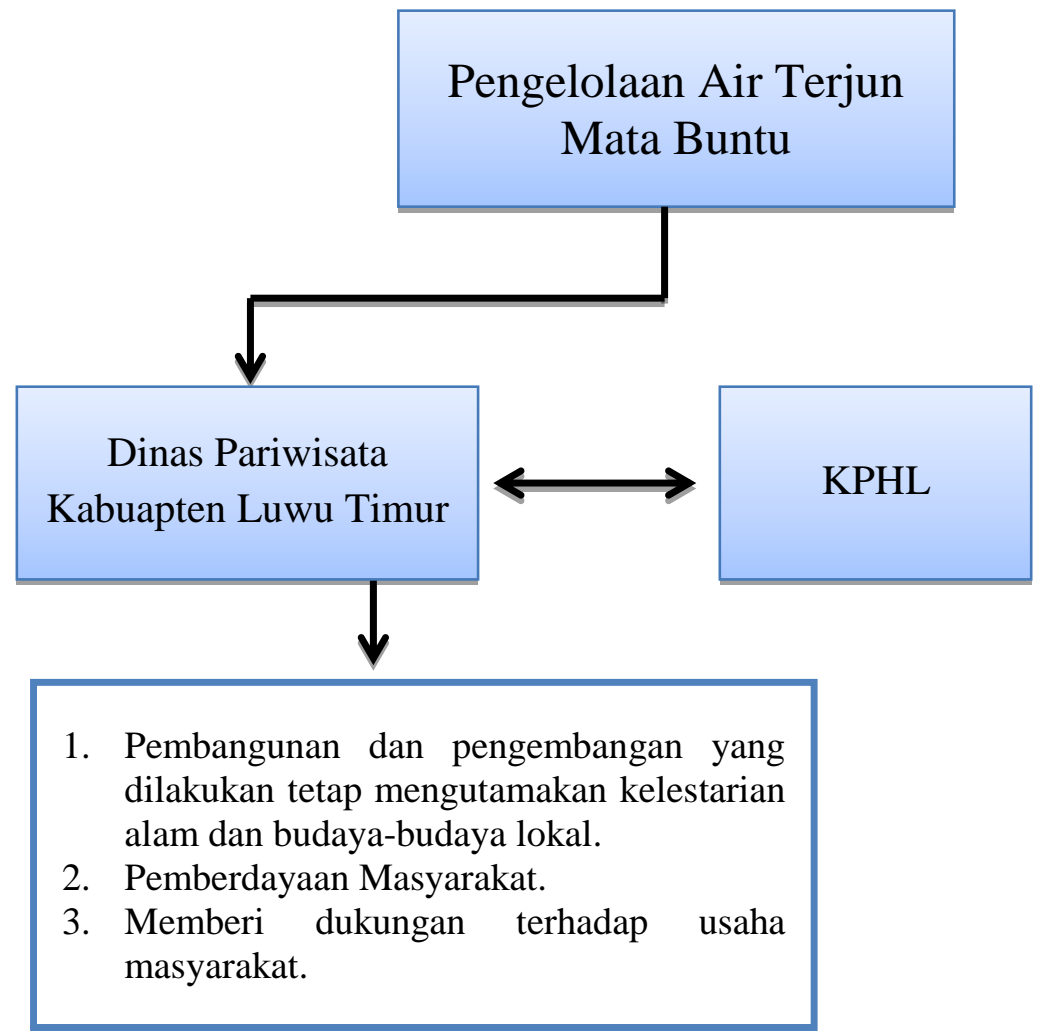

Bagan di atas menjelaskan bahwa bentuk-bentuk pengelolaan yang akan dilakukan oleh Dinas Pariwisata setelah mengambil alih pengelolaan dan mendapatkan izin pengelolaan yaitu melakukan pembangunan dan pengembangan yang tetap mengutamakan kelestarian alam dan tetap menjaga keberlangsungan hutan yang dilindungi serta tetap melestarikan budayabudaya lokal. Kemudian, Dinas Pariwisata melakukan pemberdayaan masyarakat lokal dengan memberikan arahan mengenai pentingnya pariwisata seperti memanfaatkan peluang pendapatan (membangun kios untuk warung makan dan penjualan souvenir dan makanan khas Luwu Timur), pelayanan kepada wisatawan, dan memberikan pemahaman kepada 
masyarakat akan pentingnya menjaga keamanan, kebersihan dan merawat setiap fasilitas dan keunikan dari daya tarik wisata.

Selain itu, Dinas Pariwisata memberikan dukungan kepada masyarakat yang akan membuka usaha disekitar Air Terjun Mata Buntu jika hal itu memberikan dampak yang positif. Tetapi Dinas Pariwisata juga berhak untuk memberhentikan segala usaha apabila usaha tersebut mulai merusak lingkungan dan ciri khas daya tarik wisata.

Selain Dinas Pariwisata, keterlibatan masyarakat merupakan salah satu hal yang utama dalam pengelolaan Air Terjun Mata Buntu. Ada beberapa bentu-bentuk partisipasi masyarakat sesuai dengan yang dikemukakan oleh Huraerah (2008):

1. Partisipasi berupa ide atau buah pikiran dalam sebuah rapat, pertemuan maupun musyawarah.

2. Partisipasi berupa tenaga yang diberikan dalam membantu kegiatan seperti perbaikan dan pembangunan desa, pertolongan bagi orang lain dan sebagainya.

3. Partisipasi berupa harta benda baik dalam bentuk uang, makanan dan sebagainya yang dapat diberikan kepada pihak yang melakukan perbaikan dan pembangun desa, pertolongan bagi orang lain dan sebagainya.

4. Partisipasi berupa keterampilan dan kemahiran yang diberikan dan berguna bagi orang dalam mendorong munculnya berbagai bentuk usaha dan industry.

5. Partisipasi sosial yang diberikan kepada orang lain sebagai simbol dari hubungan sosial yang baik.

Sesuai dengan pengelompokkan yang dikemukakan oleh Huraerah, maka teori tersebut dapat diterapkan pada konsep tata kelola mengenai keterlibatan masyarakat di Air Terjun Mata Buntu.

Bagan di bawah menjelaskan bahwa terdapat beberapa bentuk keterlibatan masyarakat dalam pengelolaan Air Terjun Mata Buntu. Keterlibatan masyarakat berupa membuka usaha kios atau warung makan untuk wisatawan, membuka usaha penyewaan tenda untuk berkemah dan fasilitas lainnya yang berhubungan dengan perkemahan seperti alat makan dan alat masak. Usaha penyewaan alat perkemahan dilakukan karena di Air Terjun Mata Buntu sering adanya wisatawan yang melakukan perkemahan.

Selanjutnya membuka usaha penyediaan home stay, hal ini dilakukan apabila ada wisatawan yang ingin menginap dan merasakan suasana desa di kawasan wisata Air Terjun Mata Buntu. Kemudian masyarakat setempat dapat membuka usaha jasa pelayanan berupa jasa ojek menuju ke tempat wisata. Hal ini dikarenakan lokasi Air Terjun Mata Buntu berada di pelosok desa dan jauh dari jalan utama. 


\section{Keterlibatan Masyarakat dalam Tata Kelola di Air Terjun Mata}

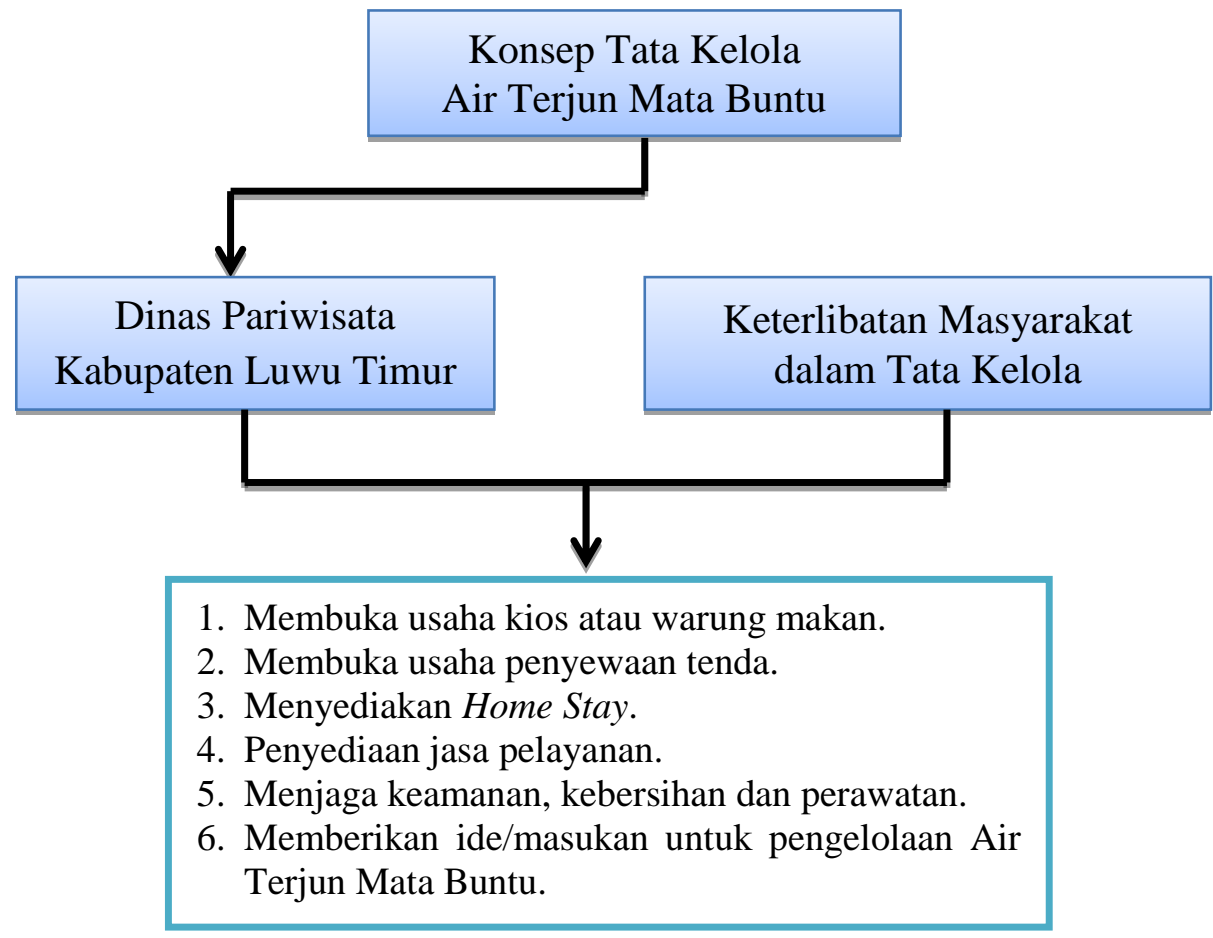

Selain keterlibatan masyarakat yang berdampak pada perekonomian seperti yang dipaparkan diatas, keterlibatan masyarakat juga bisa dalam bentuk menjaga keamanan, kebersihan dan perawatan fasilitas yang telah tersedia serta masyarakat juga dapat memberikan ide/masukan kepada Dinas Pariwisata mengenai pengeolaan dan pengembangan sesuai dengan harapan yang mereka inginkan agar menghindari konflik yang akan timbul dimasa yang akan dating.

\section{KESIMPULAN}

Tata kelola Air Terjun Mata Buntu dilakukan secara mandiri oleh masyarakat setempat, sebatas kemampuan dari masyarakat mengenai cara pengelolaan. Kegiatan pengelolaan yang telah dilakukan oleh masyarakat yaitu bergotong-royong memperbaiki akses menuju ke tempat wisata, membuka lahan parkir di tanah perkebunan miliki masyarakat, membuka warung makan atau kios untuk melayani wisatawan dan menjaga keamanan di tempat wisata. Mengenai konsep tata kelola di Air Terjun Mata Buntu belum dibuat oleh masyarakat setempat selaku pengelola di tempat wisata, 
hal ini dikarenakan masyarakat setempat hanya melakukan pengelolaan dengan memanfaatkan peluang yang mereka dapat pada saat itu.

Melihat pengelolaan Air Terjun Mata Buntu yang dilakukan oleh masyarakat hanya sekedar pengelolaan spontanitas, kepala desa setempat membuat konsep pengelolaan dan pengembangan terhadap Air Terjun Mata Buntu dengan dasar pembuatan PERDES mengenai pengelolaan Air Terjun Mata Buntu, hal ini dilakukan karena tidak adanya kejelasan dalam pengelolaan Air Terjun Mata Buntu, baik yang dilakukan oleh pihak pemerintah yaitu Dinas Pariwisata Kabupaten Luwu Timur. Tidak ikut andilnya Dinas Pariwisata dalam pengelolaan Air Terjun Mata Buntu dikarenakan, belum adanya peraturan daerah yang dikeluarkannya pemerintah tentang pariwisata secara umum di Kabupaten Luwu Timur. Konsep tata kelola yang dapat diterapkan di Air Terjun Mata Buntu yaitu (1) Dengan menggunakan fungsi manajemen (POAC) dan (2) keterlibatan stekaholder (Masyarakat setempat, Dinas Pariwisata Kabupaten Luwu Timur dan KPHL).

Konsep tata kelola Air Terjun Mata Buntu dapat dilakukan berdasarkan fungsi-fungsi manajemen yaitu planning (pembangunan anak tangga, pemanfaatan tanaman langka, menyediakan jasa keamanan, kebersihan dan maintenance); organizing (membuat struktur organisasi dengan dipimpin oleh SDM pariwisata dengan keanggotaan dilakukan oleh masyarakat setempat); actuating (menempatkan tanggung jawab setiap anggota pelaksana sesuai dengan kemampuan dan keinginan masing-masing serta pembuatan sanksi terhadap anggota pelaksana yang melanggar aturan sesuai kesepakatan); controlling (setiap kepala bagian membuat laporan pengelolaan setiap sebulan sekali kepada ketua pengelola dan ketua pengelola turun langsung kelapangan untuk melihat hasil kegiatan pengelolaan). Selain itu, dapat pula dilakukan dengan keterlibatan stakeholder (Dinas Pariwisata Kabupaten Luwu Timur, Masyarakat dan Dinas Kehutan). Agar konsep tersebut dapat terlaksana, maka sebaiknya pemerintah segera membuat PERDA mengenai pariwisata secara umum di Kabupaten Luwu Timur, dengan itu pemerintah daerah dapat mengambil alih dalam pengelolaan pada setiap potensi wisata di Kabupaten Luwu Timur khususnya di Air Terjun Mata Buntu.

\section{DAFTAR PUSTAKA}

Davis, K. 2000. Perilaku Dalam Organisasi, Edisi ketujuh. Jakarta: Erlangga.

Dinas Pariwisata, Kebudayaan, Kepemudaan dan Olahraga Kabupaten Luwu Timur. 2017.

Djamarah, S. B. 2008. Psikologi Belajar. Jakarta: Rineka Cipta. 
Huraerah, A 2008. Pengorganisasian dan Pengembangan Masyarakat: Model dan Strategi Pembangunan Berbasis Kerakyatan. Bandung: Humaniora.

Munas,B. 2011. Model Peningkatan Partisipasi Masyarakat. Jurnal Ekonomi Pembangunan Volume 12, Nomor 2:239 - 256.

Pitana,I.G dan Diarta, I.K. 2009. Pengantar Ilmu Pariwisata. Yogyakarta: Penerbit Andi.

Singarimbun,M dan Effendi,S. 2009. Metode Penelitian Survai. Jakarta: LP3ES.

Soedjadi. 2000. Kiat Pendidikan Matematika di Indonesia: Konstatasi Keadaan Masa Kini dan Harapan Masa Depan. Jakarta: Dirjen Dikti Departemen Pendidikan Nasional.

Teguh, F. 2015. Tata Kelola Destinasi Membangun Ekosistem Pariwisata. Yogyakarta: Gadjah Mada University Press.

Terry, G.R. 2000. Prinsip-prinsip Manajemen. PT Bumi Aksara:Bandung

Umar,H. 2004. Metode Riset Ilmu Administrasi. Jakarta: Gramedia Pustaka Utama.

www.luwutimurkab.go.id, diakses pada tanggal 03 April 2017. www.luwutimurkab.go.id, diakses pada tanggal 12 Januari 2017. www.palopopost.fajar.co.id, diakses pada tanggal 03 April 2017. 